\title{
The Effect of Plant Extracts on the Growth of Wilt Causing Fungi Fusarium oxysporum
}

\author{
Shweta Minz ${ }^{1}$ C. O. Samuel ${ }^{1}, \&$ S. C. Tripathi ${ }^{2}$ \\ 1. Natural Fungicide Laboratory, Department of Botany, St. Andrew's College, India. \\ 2. Natural Pesticide Laboratory, Department of Botany, D.D.U. University of Gorakhpur, India.
}

\begin{abstract}
Antifungal potential of aqueous extracts of forty plants of different families were tested against Fusarium oxysporum f.sp. ciceri causal agent of wilting of chick pea. Among forty plant species tested aqueous extract of Chenopodium ambrosioides has recorded significant antifungal activity against the test fungi. Solvent extracts viz. petroleum ether, benzene, chloroform, and methanol and ethanol extracts of Chenopodium ambrosioides was tested for the antifungal activity. Among the solvent extract tested methanol extract recorded maximum antifungal activity against the plant pathogen tested. Whereas, other plant extracts showed moderate to minimum antifungal activity. Key words: Antifungal potential, Fusarium oxysporum, Chenopodium ambrosioides, plant extracts.
\end{abstract}

\section{Introduction}

The wilt of Chick pea (Cicer arietinum L.) caused by Fusarium oxysporum f.sp.ciceri. is one of the major limiting production of the pulse crop. It is the world third most important pulse crop. At national level the yield loses encountered due to wilt may vary between five to ten percent (Vishwadhar and Gurha 1998). Synthetic fungicides are currently used as primary means for the control of plant diseases despite of their harmful effect. The demand of plant based therapeutics is increasing both in developing and developed countries as they are natural products, easily available and having no harmful effects. Keeping these facts in mind the present study deals with the study of such plant extracts which are ecofriendly and can play significant role in the protection of Chickpea from wilting.

\subsection{Collection of Plant Material}

\section{Materials And Methods}

Fresh disease free leaves of forty plant species were collected from Gorakhpur district, Uttar Pradesh (India). Selected plants were locally available in sufficient quantities.

\subsection{Preparation of Extracts}

Aqueous extract

Leaf samples of $100 \mathrm{gm}$ of all plants were washed thoroughly with sodium hypochlorite solution and finally with sterile distilled water, air dried and then ground with the help of sterile pestle and mortar. Extracts were filtered through double layered Whatman No. 1 filter paper and heat sterilized in an autoclave at $121{ }^{\circ} \mathrm{C}$ for $30 \mathrm{~min}$. Extracts were stored aseptically in airtight bottles and served as mother extract.

\section{Solvent extract}

Twenty five gram of dried powder of each plant was filled in a thimble and extracted successively with petroleum ether, benzene, chloroform, methanol and ethanol. All extracts were preserved at $4^{\circ} \mathrm{C}$ in an air tight bottle for further use. All extracts were subjected to antifungal activity against the test fungi.

\section{Test Fungi}

The fungal strain of Fusarium oxysporum was obtained from the Microbial Type Culture (MTCC), Chandigarh (India Collection). The culture was maintained on PDA medium, which was served as the test fungi for antifungal activity.

\subsection{Antifungal Activity Assay \\ Aqueous extract:}

PDA medium with 50\% aqueous extracts of the test plants were prepared and autoclaved and poured into pre sterilized petriplates (17ml each) and allowed to solidify. After complete solidification of the medium, five $\mathrm{mm}$ disc of seven day old culture of the test fungi were placed aseptically in the centre of the petriplates and incubated at $28 \pm 2^{\circ} \mathrm{C}$ for six days and observation were recorded on seventh day. The colony diameter was 
recorded in terms of millimeters. PDA medium devoid of extract served as control. For each treatment four replicates were maintained. The fungitoxicity of extracts was calculated in terms of percent inhibition of mycelia growth by using the formula: \% inhibition $=\mathrm{dc}-\mathrm{dt} / \mathrm{dc} \times 100$

Where, $\mathrm{dc}=$ Average increase in mycelia growth in control.

$\mathrm{dt}=$ Average increase in mycelia growth in treatment. (Singh and Tripathi 1999).

\section{Solvent extract:}

One gram of each of the dried evaporated solvent extract of all the test plants was dissolved in $10 \mathrm{ml}$ of methanol. 500 $\mu$ of each of the solvent extract was amended with $15 \mathrm{ml}$ of PDA medium before solidification of the medium. The medium amended only with $500 \mu \mathrm{l}$ of methanol served as control. Fusarium oxysporum was inoculated and percent inhibition of the mycelia growth was determined as described earlier.

Aqueous extract:

III. Result

Antifungal activity was screened by agar dilution method (Perez et al; 1990). The result revealed that the extract of Chenopodium ambrosioides showed significant reduction in the growth of Fusarium oxysporum. The percent inhibition of aqueous extract of thirteen plants was more than $50 \%$ against the test fungus.

\section{Solvent extract:}

The present study revealed that the methanol and ethanol extracts had a higher fungitoxic activity against Fusarium oxysporum than the aqueous extracts. Methanol was tested more effective which was followed by ethanol, chloroform, benzene and petroleum ether. In case of Chenopodium ambrosioides,Lippia alba and Carum carvi the percent inhibition was more than $90 \%$. Therefore this study suggests these plant extracts would be helpful in treating wilting disease in Cicer arietinum field.

\section{Discussion}

Many agriculturally important pesticides has been banned by World Health Organization (WHO) due to their wide range of toxicity against non target organisms including humans, which are known to cause pollution problem (Barnard et al 1997).

The results are quite encouraging because most of the extracts screened showed antifungal efficacy of more than $90 \%$ for the test fungus. The screening revealed that Chenopodium ambrosioides plant was most effective, also thirteen plants showed moderate activity against the test fungi. The present study can play important role in crop protection by developing plant based pesticides which are ecofriendly.

TABLE (1). Antifungal Assay of Plant Extracts by Poisoined Foof Technique

\begin{tabular}{|c|c|c|}
\hline & & tion of Mycelial \\
\hline S.No. & Plants & \\
\hline 1 & Allium sativum & 58.0 \\
\hline 2 & Artemisia nilagirica & 83.0 \\
\hline 3 & Azadirachta indica & 82.0 \\
\hline 4 & Capsicum аппит & 78.0 \\
\hline 5 & Carum carvi & 99.0 \\
\hline 6 & Centella asiatica & 80.0 \\
\hline 7 & $\begin{array}{l}\text { Chenopodium } \\
\text { ambrosioides }\end{array}$ & 100.0 \\
\hline 8 & Cymbopogon citrates & 76.0 \\
\hline 9 & Lippia alba & 99.0 \\
\hline 10 & Mentha arvensis & 65.0 \\
\hline 11 & Riccinus communis & 85.0 \\
\hline 12 & Vitivera zizanoides & 68.0 \\
\hline 13 & Zinziber officinale & 82.0 \\
\hline
\end{tabular}




\section{Chenopodium ambrosioides}

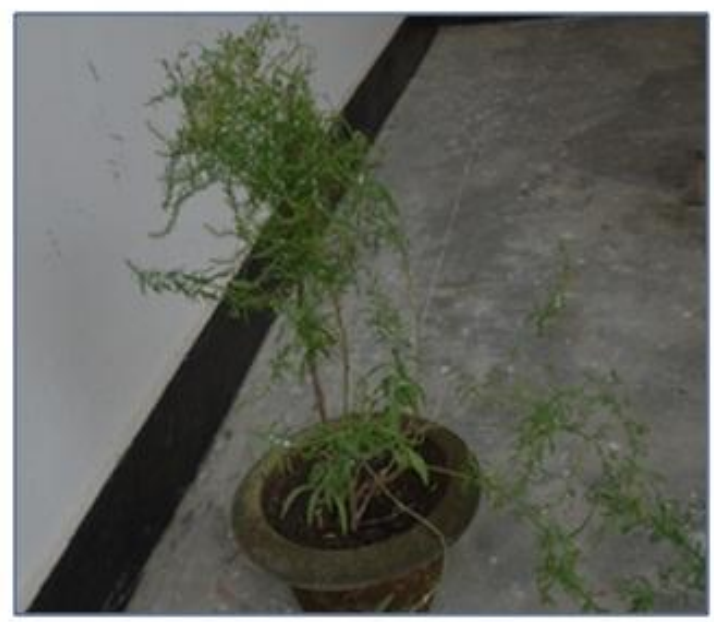

Lippia alba

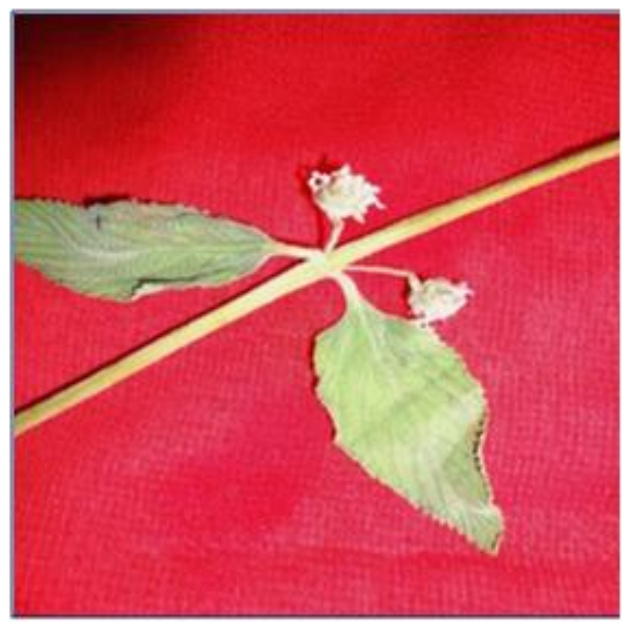

Carum carvi

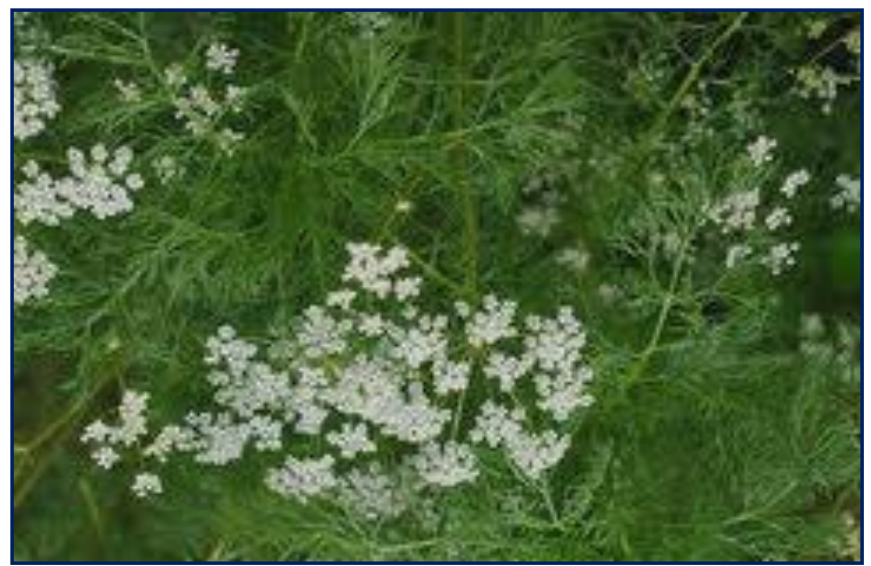

Table (2). Antifungal Activity of Different Solvent Extracts Against Fusarium oxysporum

\begin{tabular}{|c|c|c|c|c|c|c|}
\hline $\begin{array}{c}\text { S.No. } \\
1\end{array}$ & $\begin{array}{l}\text { Plant species } \\
\text { Allium sativum }\end{array}$ & $\begin{array}{l}\text { Petrolium } \\
\text { ether } \\
40.45 \pm 1.45\end{array}$ & $\begin{array}{c}\text { Benzene } \\
47.80 \pm 1.52\end{array}$ & $\begin{array}{l}\text { Chloroform } \\
56.15 \pm 0.56\end{array}$ & $\begin{array}{c}\text { Methanol } \\
82.26 \pm 6.50\end{array}$ & $\begin{array}{l}\text { Ethanol } \\
78.45 \pm 2.10\end{array}$ \\
\hline 2 & $\begin{array}{l}\text { Artemisia } \\
\text { nilangirica }\end{array}$ & $46.45 \pm 1.56$ & $54.39 \pm 1.56$ & $66.56 \pm 1.56$ & $89.56 \pm 1.63$ & $75.23 \pm 1.56$ \\
\hline 3 & $\begin{array}{l}\text { Azadirachta } \\
\text { indica }\end{array}$ & $41.25 \pm 0.56$ & $49.23 \pm 2.35$ & $56.45 \pm 0.56$ & $83.48 \pm 1.27$ & $74.29 \pm 3.15$ \\
\hline 4 & Capsicum annum & $41.25 \pm 1.49$ & $47.05 \pm 3.56$ & $55.40 \pm 1.56$ & $84.23 \pm 0.36$ & $72.81 \pm 2.80$ \\
\hline 5 & Carum carvi & $44.23 \pm 0.65$ & $56.25 \pm 1.56$ & $64.75 \pm 0.47$ & $92.68 \pm 1.35$ & $80.45 \pm 2.46$ \\
\hline 6 & Centella asiatica & $45.19 \pm 1.08$ & $50.36 \pm 1.12$ & $64.35 \pm 1.80$ & $72.25 \pm 1.05$ & $78.58 \pm 1.12$ \\
\hline 7 & $\begin{array}{l}\text { Chenopodium } \\
\text { ambrosioides }\end{array}$ & $46.28 \pm 1.78$ & $55.52 \pm 0.58$ & $65.29 \pm 2.50$ & $97.65 \pm 1.55$ & $82.20 \pm 2.45$ \\
\hline 8 & $\begin{array}{l}\text { Cymbopogon } \\
\text { citrates }\end{array}$ & $38.15 \pm 1.56$ & $52.45 \pm 1.23$ & $62.25 \pm 1.89$ & $74.20 \pm 2.3$ & $78.80 \pm 1.25$ \\
\hline 9 & Lippia Alba & $45.60 \pm 1.56$ & $50.28 \pm 2.66$ & $66.82 \pm 3.20$ & $94.45 \pm 2.30$ & $81.45 \pm 2.25$ \\
\hline 10 & Mentha arvensis & $36.15 \pm 1.56$ & $56.28 \pm 1.12$ & $66.38 \pm 1.90$ & $74.40 \pm 1.20$ & $76.25 \pm 1.23$ \\
\hline 11 & $\begin{array}{l}\text { Riccinus } \\
\text { communis }\end{array}$ & $42.85 \pm 0.45$ & $52.12 \pm 1.23$ & $65.75 \pm 1.05$ & $72.94 \pm 1.51$ & $75.73 \pm 1.45$ \\
\hline 12 & Vivera zizanoides & $40.24 \pm 0.65$ & $50.23 \pm 3.54$ & $66.05 \pm 8.50$ & $86.35 \pm 1.26$ & $74.46 \pm 2.36$ \\
\hline 13 & Zinziber officinale & $44.15 \pm 1.56$ & $49.89 \pm 6.23$ & $58.80 \pm 5.30$ & $85.29 \pm 2.46$ & $81.28 \pm 4.16$ \\
\hline
\end{tabular}




\section{Control with treatment set of Chenopodium ambrosioides}

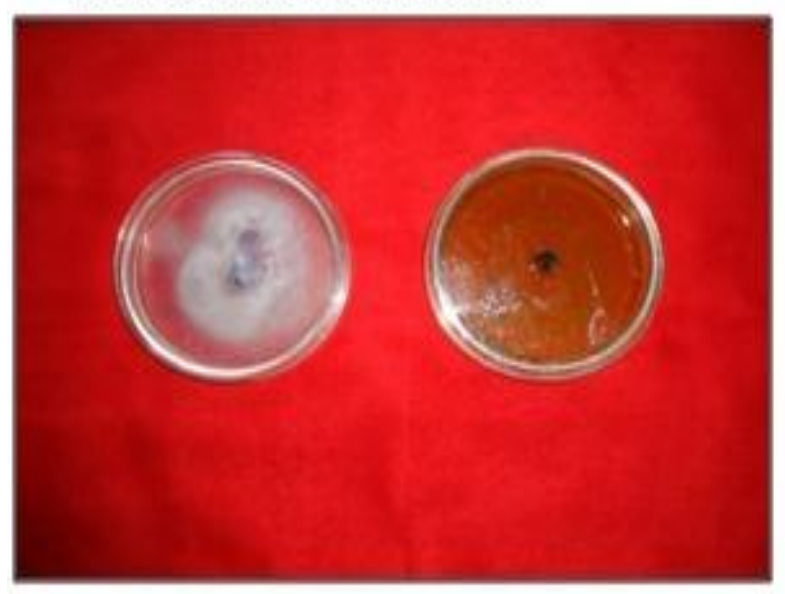

\section{Control with treatment set of Lippie Alba}

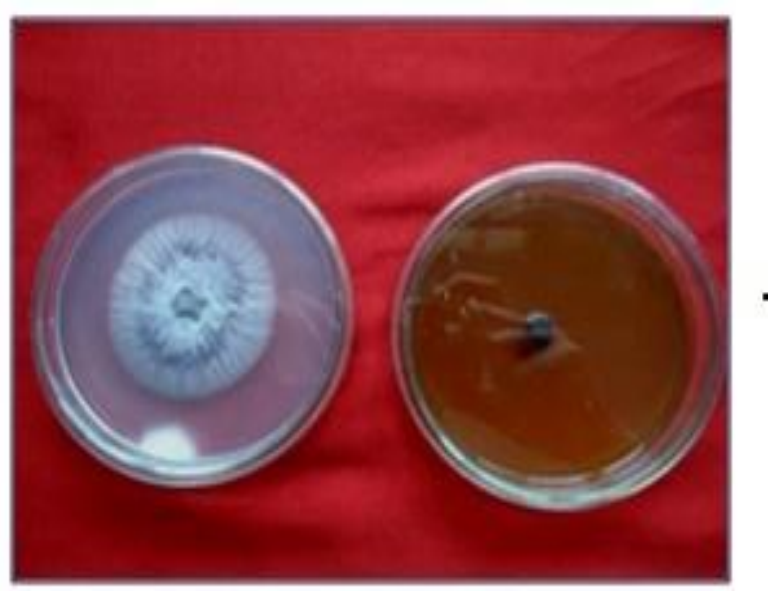

\section{Control and treatment set of Carum carvi}

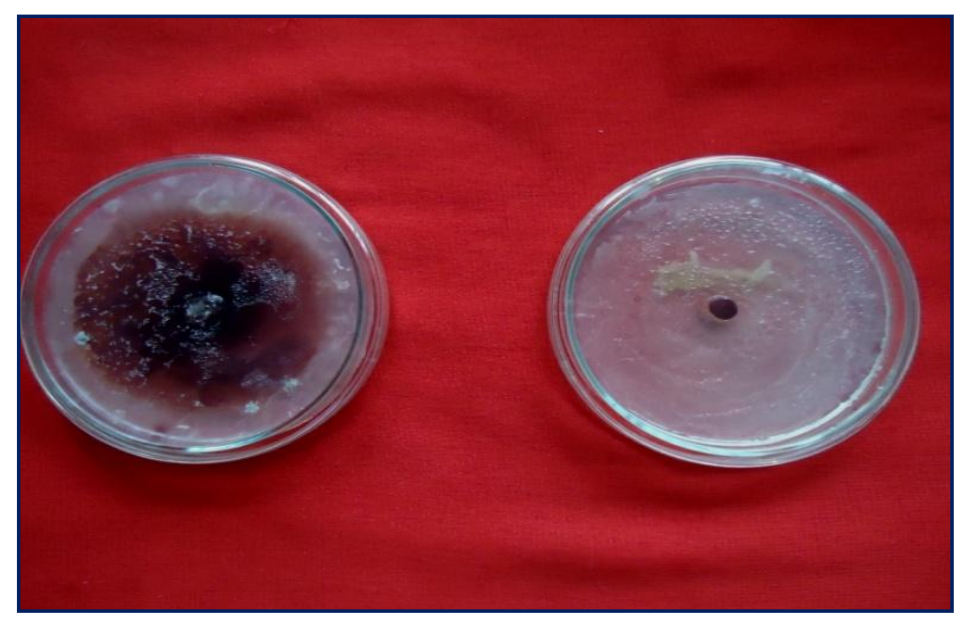

\section{References:}

[1] Barnard, C; Padgitt, M. and Uri, N.D. (1997). Pesticide use and its measurement. International Pest Control 39:161-164.

[2] Gottlieb, O.R; Borin, M.R. and Brito, N.R. (2002) Integration of ethnobotany and phytochemistry: dream or reality? Phytochemistry 60:145-152.

[3] Perez C, Paul M, Bazerque P, (1990). Acta Bio Med Exp 15:113-115.

[4] Singh, J and Tripathi, N.N. (1999). Inhibition of storage fungi of blackgram ( Vigna mungo) by some essential oils. Flavour and Fragrance Journal 14: 1-4.

[5] Verma, J. and Dubey, N.K. (1999). Prospectives of botanical and microbial products as pesticides of tomorrow. Current Science 76; 172-179.

[6] Vishwadhar, Gurha SN (1998). Integrated management of Chickpea diseases. Integrated pest and disease management. Rajeev, k; Upadhyay, K.G; Mukerji, B.P; Chamola and Dubey, O.P. (eds.) APH Publishing Co; New Delhi. (India). P.249. 